\title{
Anéis de prata: alunos e professores na sociedade da comunicação*
}

\section{Silver rings: students and teachers in a media society}

\author{
Heloisa Pait** \\ Mas o professor ficou imóvel e não entregou o cader- \\ no. \\ Para a minha súbita tortura, sem me desfitar, foi ti- \\ rando lentamente os óculos. E olhou-me com olhos \\ nus que tinham muitos cilios. Ele me olhava. E eu \\ não soube como existir na frente de um homem. \\ - Como é que lhe veio a idéia do tesouro que se dis- \\ farça?
}

Os desastres de Sofia, Clarice Lispector

\begin{abstract}
RESUMO
Qual o papel do professor numa sociedade saturada de informação e marcada por mudanças constantes em suas esferas comunicativas? Ele deve resistir a essas mudanças ou aceitá-las acriticamente? Mostramos aqui que a preservação do núcleo central da relação professor-aluno é crucial para termos um diálogo público rico em nossas sociedades. Através de breves narrativas, refletimos sobre as estratégias usadas por professores para navegar em distintos espaços comunicativos. Os quatro tipos de professor apresentados são o professor do livro, o professor teatral, o professor televisivo e o professor telegráfico. Essa tipologia se re-
\end{abstract}

* Esse artigo reelabora o capítulo 4 de minha tese de doutorado, que contou com o apoio da Capes-Coordenação de Aperfeiçoamento de Pessoal de Nível Superior. Agradeço também a bibliotecária Marisa Rocha, pela inteligente edição do artigo.

** Doutora em Sociologia da Comunicação pela New School for Social Research e professora do departamento de Psicologia da Educação da Faculdade de Ciências e Letras de Araraquara da Unesp- Universidade Estadual Paulista. E.mail: hpait@ffclar.unesp.br 
fere a modos de incorporar e dar sentido a formas mediáticas distintas. Atenção especial é dada ao professor televisivo, aquele responsável pela organização de informação dispersa e também por ajudar os alunos a tolerar a eventual falta de sentido do campo comunicativo criado pela televisão. Palavras-chave: ensino, mídia, televisão, silêncio, espaço público.

\begin{abstract}
What is the role of teachers in a world of massive information and constantly shifting media spheres? Should he or she resist such changes or accept them acritically? We show here the core of the student-teacher relationship should be preserved if we are to create and maintain a rich public dialogue in our societies. Through pieces of prose, we reflect upon teachers' strategies for navigating complex media spaces. We present four types of teachers: the teacher of the book, the theatrical teacher, the televisual teacher, and the telegraphic teacher. Particular attention is given to the televisual teacher, who is responsible for organizing dispersed information as well as helping students withstand the eventual lack of meaning without ever abandoning the communicative game proposed by television.

Key-words: education, media, television, silence, public space.
\end{abstract}

\title{
Introdução
}

Na sexta série tínhamos uma professora que resolveu nos dar $A$ história da riqueza do homem para ler. Ela enganchava os dedos de sua mão, repletos de anéis de prata, nos dedos da outra mão e puxava os braços para fora, num gesto impossível. "O servo não existe sem o senhor, o senhor não existe sem o servo!", ela bradava, com raiva de nós. Quando fui estudar dialética, pensava no Leo Huberman, pensava nos anéis de prata com pedras turquesa da professora Isabel, pensava na relação de admiração e brigas que tínhamos com ela. Sim, aprendemos a transição do feudalismo para o capitalismo, nós que éramos burgueses e fazíamos bagunça. Eram aqueles dois braços, querendo se afastar, para sempre juntos.

Aprendemos com a presença da professora Isabel na sala de aula, com suas dúvidas, certezas e com a maneira engraçada, agressiva ou interessada, 
com que as expunha. O que significa ensinar hoje, num ambiente de mídia em que vivemos? É ainda possível encontrar professoras que nos intriguem como a professora Isabel? Nesse artigo, vamos examinar o significado da relação de aprendizado e os desafios enfrentados pelos professores numa sociedade com o nosso ambiente de mídia. Sustento que cabe a eles encontrar seu lugar como professores numa sociedade mediada, e às instituições de ensino apoiálos. A busca desse lugar exclui adesão ou resistência à invasão dos meios de comunicação em nossa vivência comunicativa. Trata-se de assumir posturas e criar formas comunicativas em sala de aula que dêem aos alunos capacidade de dialogar e atuar numa sociedade de comunicação complexa.

A questão sobre o papel do professor numa sociedade mediada surgiu de minha pequisa de doutorado sobre o tipo de comunicação trazido pela televisão no Brasil (PAIT, 2003; 2005a). Estudando as expectativas, memórias e desejos de escritores de novela e espectadores, percebi que havia algo intrinsecamente frustrante na experiência de fazer parte de um espaço criado pela televisão. Ele atiça a participação num debate público que ocorre plenamente só num espaço virtual e fragmentariamente na interação real entre as pessoas. É um diálogo mudo que ocorre entre autores e espectadores, mas de grande importância para os diálogos "barulhentos" dos espaços públicos tradicionais (PAIT, 2005b).

Chamei de "silencioso" o modo como os brasileiros lidaram com esse paradoxo da comunicação mediada, talvez influenciada pela ficção de Clarice Lispector, autora que devotou tanta atenção ao não-dito, ao que fica nas entrelinhas e é compartilhado de modo incerto. No conto $A$ repartição dos pães (1992), por exemplo, ela descreve um almoço social sem nada dizer sobre o que se falou nele, ou mesmo quem eram os convidados. O que ela conta é o estar nesse almoço, a partir dos olhares, movimentos e desejos envolvidos. Como Winnicott (BERTOLINI et al., 2001), entre outros, ela está preocupada com o ambiente onde a interação acontece, mais do que com ações e falas concretas, e essa atenção ao que pode ocorrer - mais do que ao que ocorre - é que nos inspirou em nossa investigação. Na tese, falei desse "silêncio" me referindo à capacidade de suportar a frustração de habitar um complicado espaço comunicativo, e ainda assim se engajar nele ativa e interessadamente. Mesmo quando os outros participantes desse espaço não são vistos, ouvidos ou mesmo conhecidos, os brasileiros não abandonaram o jogo de adivinhar quem estava compartilhando tal espaço com eles, e também como o faziam.

Os espectadores habitam a fratura que é a tela de televisão. Eles têm a difícil tarefa de entender a contradição entre estar junto e estar isolado como prática diária. Os leitores brasileiros e americanos desse texto podem consi- 
derar esse jogo de adivinhação algo banal, de tão parte que é de nossas culturas. Talvez vejam essa abertura do espectador a outros espectadores desconhecidos uma conseqüência imediata da prática de ver TV. Mas não devemos fazer isso. Nada garante que os espectadores não vão apropriar a televisão como um objeto de consumo individual, ou que eles não vão assumir que uma apropriação homogênea de imagens e sons recebidos ocorre em todas as casas. Que as pessoas especulem sobre as ações dos outros é já uma expressão de sua própria cultura política, ou ao menos uma decisão exigida pela introdução de novos meios de comunicação, e portanto de novos dilemas.

É claro que hoje a construção de um espaço nacional televisivo não é mais um desafio. Já a compreensão do espaço público global é uma tarefa que exige empenho de emissores e receptores de imagens e narrativas para que esse espaço se torne vivo e democrático. De qualquer modo, o desafio de habitar um novo espaço comunicativo se repõe. E quem nos ajuda nesse desafio? Quem pode nos ajudar a habitar as fraturas da comunicação e os espaços mediáticos em constante mutação que nos distraem e fascinam? Foi com essas questões que fechei minha tese, e que começo esse artigo.

$\mathrm{Na}$ próxima parte, reflito sobre a complexidade emocional da relação professor-aluno. Na parte 2, especifico os desafios que a comunicação mediada nos apresentam. Na parte 3, quatro breves narrativas mostram como certos professores podem lidar com esses desafios. Na parte 4, devoto especial atenção ao que chamo de professor televisivo, tão necessário em nossos dias de informação massiva e espaços comunicativos em constante transformação.

\section{O fascínio do aprendizado}

Voltando à professora Isabel, que relação era aquela? O que, apesar de nossos conflitos, nos impelia a olhá-la e escutá-la? Que tipo de "outro" é esse que definiu como sua tarefa a de apresentar o mundo às novas gerações? Pena Simmel não ter formalizado essa relação em seus escritos. O sociólogo berlinense estudou o estrangeiro, que ao mesmo tempo pertence à sociedade e lhe é um estranho, e a prostituta, que vende o que tem de mais pessoal pela recompensa mais impessoal (sIMMEL, 1971). Nesse jogo de contrários estava a especificidade de cada papel social, sua beleza e peculiaridade. O estrangeiro, por exemplo, enxerga, dessa posição ambígua, coisas que o nativo não 
consegue. Cabe a nós, modestamente, procurar decifrar o papel do professor em uma sociedade em constante mutação. Que tipo de olhar é o dele, que troca propõe? Que papel incorpora quando entra no palco da sala de aula? Mas nessa parte vamos apenas destacar elementos que nos parecem perenes nessa relação, que parecem ser parte do próprio ato de aprender e ensinar, e para isso vamos retomar as idéias de um psicanalista, um filósofo e uma escritora, deixando as formas sociais para depois.

Para o psicanalista Wilfred Bion (o'shaughnessy, 1988), o ato de pensar é já uma relação humana. Ele mostrou que o próprio processo de pensar é melhor descrito como uma abertura emocional para uma outra pessoa. Essa abertura é aprendida quando somos, inicialmente, compreendidos: nossa constituição como sujeitos cognitivos ocorre então numa relação bastante complexa. Aprender, para Bion, é em primeiro lugar compreender o outro e, através disso, dar sentido ao mundo. Longe de ser apenas um fracasso cognitivo, então, não poder ou não querer pensar, para o psicanalista britânico, é um fracasso numa relação humana.

Lévinas (1981) segue numa direção bastante parecida. Para o filósofo, a face do outro é irredutível ao entendimento completo, e ao mesmo tempo chama sempre por algum tipo de resposta. O rosto do outro é um apelo. Para ambos os autores, é essa relação com outra pessoa que ao mesmo tempo dá lugar e provoca o pensamento. Para eles, pensar é desde o início aprender, aprender alguém, e está então envolvido num mar de implicações éticas e emocionais. As emoções que entram nesse processo vão de raiva à cumplicidade, entusiasmo e decepção, inveja e divertida competição, mas vêm acima de tudo de um profundo interesse no outro, sem o qual nem se pode falar em aprender, ou ensinar. O romance de Connie Palmen (1993) sobre uma estudante de filosofia em busca das "leis" é extremamente rico na descrição dessas emoções. Quando a personagem se relaciona sucessivamente com um epilético, um astrólogo, um físico e um padre, somos jogados com ela numa série de encontros com modos de pensar que, longe de nos esclarecer, pedem novos encontros e trazem novas questões, fazendo do romance um permanente confronto com formas de pensar desconhecidas. No caso, com as leis dos homens.

Para esses autores, o outro nos fascina. Podemos acompanhar seus movimentos, mas não entendê-los completamente, e é esse entendimento apenas provisório que nos impele a continuar buscando o outro e o entendimento desse outro. Na psicanálise, Bion abandona o desejo erótico e maternal como força de interação primordial e abre espaço para um tipo de desejo cognitivo, o desejo de compreender o outro, e um tipo de satisfação cognitiva que vem 
com o estabelecimento de uma relação de aprendizado mútua. Para Lévinas, o ético é mobilizado pelo desconhecimento desse outro que se apresenta como estrangeiro. E as aventuras da personagem de Palmen são, acima de tudo, aventuras intelectuais, onde conhecimento, o corpo e o outro estão ligados inextrincavelmente.

É essa íntima relação entre o pensamento e relações humanas emocionais e éticas que nos permite afirmar que os professores ainda têm hoje um papel central no processo de aprendizado, apesar das dificuldades que a educação contemporânea apresenta a eles. Essas dificuldades são bem reais. Citamos aqui a subordinação das escolas a lógicas comerciais, a abundância de informação que parece colocar o professor numa posição redundante, além de indefinições na própria relação professor-aluno que geram alunos apáticos ou indisciplinados. É possível, e até necessário, resistir a certas mudanças institucionais, e procurar moldar as interações dos alunos com a mídia. Mas é mais importante redefinir o papel do professor num novo contexto mediático e institucional, fortalecendo-o. Esse artigo procura refletir sobre esse novo papel, essa reinscrição do aprendizado numa sociedade mediada. Em outras palavras, a industrialização dos processos educativos e a abundância de informação em nossas sociedades não pode tratar os professores como computadores velhos. Se o aprendizado é acima de tudo uma relação humana, a questão não é o que fazer com o obsoleto ser humano com seus constrangedores giz e voz, mas sim o que constitui a relação de aprendizado numa sociedade mediada, e quem o professor é hoje, ou pode ser.

Claro que muito mais já foi escrito sobre a relação professor-aluno, mas com essa breve exposição queremos apenas destacar o caráter humano, ético, da relação que se estabelece entre alunos e professores num espaço onde a fala e a escuta, a reflexão e o questionamento, o conhecido e o desconhecido têm lugar. Um espaço - a sala de aula - onde uma geração diz a outra o que é o mundo, no sentido que Arendt dá ao termo (ARENDT, 2003), e o entrega com medo e expectativa.

\section{O silêncio da televisão}

Mas qual é exatamente esse ambiente mediático, e quais os desafios que ele nos coloca? Vamos nessa parte descrever esse ambiente, especialmente no 
que diz respeito ao modo como os meios de comunicação afetam nossas práticas comunicativas, para que possamos ter um idéia dos desafios enfrentados pelos professores hoje, pois é especialmente o ensino da habitação de um espaço comunicativo que temos em mente. A questão da materialidade da comunicação em geral é tratada por Debray (1996), entre outros (GUMBRECHT et al., 1994; MCLUHAN, 1994). Comecemos pelo óbvio: nosso ambiente mediático tem um forte componente visual. Isso começa com fotografia, filme, a transformação visual da grande cidade, e continua ao longo do século XX com a televisão e mais recentemente com o computador pessoal. A capacidade de olhar e enxergar coisas em imagens trazidas de longe passou a ser uma exigência constante em nossas vidas. Muitos já escreveram sobre o papel da televisão em nossas vidas (FISKE, 1997; MEYROWITZ, 1985), e alguns lidaram especificamente com o meio televisivo, como Cavell (1982) e Weber (1996).

Para Cavell, a característica da televisão é um equilíbrio delicado entre os acontecimentos e a falta deles. A televisão monitora o mundo a cada segundo, na tentativa de capturar o evento quando ele ocorre. O formato serial da televisão, seu formato por excelência, apresenta um tempo contínuo no interior do qual movimentos isolados ocorrem. Weber já reflete sobre as complicações espaciais que a televisão traz. O meio, que poderia eliminar a distância, na verdade faz o oposto: leva a distância para casa. Antes dela, o espaço imaginado era em linhas gerais o espaço visível - claro que desde o tempo das grandes descobertas isso não é bem assim, e o homem sempre imaginou espaços remotos. Mas, com a televisão, essa imaginação é cotidiana, fácil, quase imediata. A televisão cria um espaço onde as coisas visíveis estão longe.

Se Cavell e Weber estão certos, os dilemas de nosso mundo televisivo estão postos. Em primeiro lugar, se a televisão monitora o mundo em busca de eventos, nós devemos ser capazes de identificar quando um evento está ocorrendo, ou seja, quando um fato relevante é mostrado, ao lado de uma pluralidade de cenas também ocorridas, mas que pertencem ao fluxo cotidiano de acontecimentos. Nossos olhos devem ser capazes de selecionar e catalogar imagens não obviamente importantes. E, em segundo lugar, temos que conviver com a distância. Entender que mesmo que objetos apresentados na tela estejam longe de nós, eles são reais, e vice-versa, que objetos que pertencem ao nosso mundo estão fora de nosso alcance. E por que seria tão difícil conviver com essa distância?

A transmissão de texto, som e imagem pelo telégrafo, rádio e televisão conecta emissores e receptores que, na maior parte das vezes, são desconhecidos uns dos outros. Esses meios de comunicação tornam possível essa comu- 
nicação a distância, assim como a pintura e a literatura já tinham quebrado a barreira do tempo. Posso reparar que meu irmão lembra um pouco um tataravô por causa de uma fotografia vista na casa da tia Adélia. Mas imagino que o homem na foto nunca tenha visto a face de seu próprio tataravô, que viveu, calculo, na segunda metade do século XVIII, quando encomendar um retrato custava uma fortuna. Imaginar um mundo sem imagens e textos do passado é, hoje, um exercício bem difícil.

Do mesmo modo, posso conversar com minha sobrinha em Boston, pois ligações internacionais são bem baratas hoje em dia. Mas esses dois atos, por si mesmos, de conversar com sobrinhas ou ver um rosto à sua frente, não são tão insólitos. A coisa muda de figura se estamos falando de sermos vistos por milhões de pessoas: isso é em si mesmo inconcebível sem meios de comunicação poderosos. Veja esse exemplo cotidiano. Uma conhecida encontrou um ator de novelas num bar e disse a ele: "Eu me lembro de você de algum lugar." Ele foi seco, disse que não a conhecia. Ela insistiu: "Não pode ser, você fez FAU? Não é da turma do Yoshi, da Tatá, do Gordo?" Aí o moço a tratou muito mal, e ela saiu de cena educadamente. Por que o ator não pode simplesmente dizer: "Não estudei na FAU; sou ator de novelas, você já deve ter me visto na tela de televisão.’? Claro que ele pode ter sido simplesmente antipático, mas é fato que rejeitou completamente uma relação de conhecimento que obviamente estava lá. Era como se na sua mente não houvesse um lugar para ser conhecido por milhões de pessoas que ele nunca viu. Pode-se falar com uma pessoa de longe, mas não se pode ter uma conversa com milhares de pessoas, e a antipatia do ator está ligada com essa impossibilidade.

A introdução de novos meios de comunicação nos coloca essas questões, mas não nos oferece respostas. E tais questões são fundamentalmente éticas, pois tem a ver com o modo como nos relacionamos uns com os outros. A decisão a respeito do que fazer com imagens e sons transmitidos para nossas cidades, casas e computadores é uma decisão humana, com tudo o que isso acarreta. Na minha tese de doutorado (PAIT, 2003) chamei de silencioso o modo de participação num novo ambiente comunicativo que permite que questões que procuram emendar as fraturas da comunicação sejam colocadas. Dei esse nome, pois acredito que essas questões não pertencem ao universo interpretativo somente, mas dizem respeito à própria base onde a comunicação ocorre. Esse silêncio está mais perto de um olhar que pode mapear uma paisagem mediática do que de uma questão mesmo, passível de ser respondida. Mas tentemos colocar essas questões em palavras mesmo assim: Quem está vendo esse programa comigo? Os personagens na tela vão escutar meus conselhos? Meus amigos sabem que estou interessado nos destinos da 
heroína Helena? Num novo meio de comunicação, essas questões de fundo estão ainda frescas, e podem ser colocadas sem constrangimentos. Observe como crianças pequenas expressam suas dúvidas abertamente sobre telefone, televisão ou fotografias, enquanto nós apenas nos damos o direito de fazer isso com novos aparelhinhos celulares e programas de computador. Mas o entusiasmo delas e nosso têm a mesma raiz: surpreendemo-nos com quem está lá conosco, quem pode nos ouvir e quem estamos vendo de verdade.

Aí é que vem o professor. Ele é responsável por nos ensinar como viver com as ambigüidades da comunicação de massa - e se não o fizer, teremos muita dificuldade em compreender esses sons e imagens que vêm dos quatro cantos do mundo. Claro que ele não vai fazer emendas nas fraturas da comunicação: temos que ter sempre em mente que isso é impossível, já que estamos falando em sistemas comunicativos que envolvem milhões ou bilhões de pessoas. Mesmo a comunicação um-a-um que o telefone e a internet proporcionam para fins comerciais e de lazer são bem complexas: elas formam parte de uma rede oscilante onde continuamos com um o diálogo que iniciamos com outro no dia anterior, sendo apenas aparentemente um-a-um. Mas sua tarefa não pode ser equiparada à mera alfabetização digital. A questão não é como usar a internet e o vídeo, mas como se portar numa sociedade de telas, de aberturas para outros espaços. Uma coisa é ensinar a ler e escrever, a manejar letras e espaços. Outra coisa é preparar o aluno para o momento em que ele terá a liberdade e a responsabilidade de ler e de escrever: para viver num mundo onde ele não poderá mais dizer: "não sei".

Estamos em busca de um professor que pode interpretar os ambientes mediáticos como se fosse um ator, mantendo a mágica do ensino intacta. $\mathrm{E}$ nesse ato interpretativo, mostrar o potencial da comunicação mediada, "dizer" maneiras de falar e de ouvir num ambiente comunicativo estranho e difícil sem perder a esperança de poder ouvir o que os outros dizem e responder a eles. Nas narrativas a seguir quero sugerir modos diversos pelos quais alguns professores puderam incorporar meios de comunicação particulares de modo bastante pessoal. Acredito que os professores retratados conseguiram preservar o caráter mágico de seu papel, e o fizeram sem na verdade resistir a novos ambientes de mídia, mas escolhendo aqueles ambientes que lhes permitiam expressar suas próprias facetas individuais. Eles não usam a mídia como instrumento: ela é uma forma de pensar mais que tudo. Esses professores agem e se apresentam de tal modo que páram a máquina de ensino da qual poderiam se tornar peças mecânicas. 


\section{Quatro professores}

Agora vamos juntar duas coisas sobre as quais raramente refletimos em conjunto. Quando pensamos em ensinar, pensamos em ensinar coisas, ou técnicas, ou mesmo sociabilidades. Se falamos no ensino de comunicação, pensamos em auxiliar o aluno na busca de modos de comunicação já estabelecidos, que nos são familiares. Quando os meios de comunicação entram na conversa, é geralmente pensando em temas como inclusão digital, ou seja, no aprendizado de novas tecnologias. Nossa questão tangencia essas todas, mas seu núcleo é a questão da postura numa sociedade mediada. Como ver, como pensar, como falar e escutar, e como agir numa sociedade mediada? Anteriormente ressaltamos o aspecto ético do ensino e do aprendizado, ou seja, seu caráter humano, e descrevemos os desafios que as pessoas comuns enfrentam para falar e escutar numa sociedade mediada. Agora vamos sugerir quatro formas de ser professor: de propor aos alunos estratégias e posturas para viver numa sociedade mediada, e na quarta parte vamos explicar em mais detalhes que posturas são essas. Os quatro tipos de professor que apresentarei são: o professor do livro, o professor teatral, o professor televisivo e o professor telegráfico. Essa tipologia se refere a modos de incorporar e dar sentido a formas mediáticas distintas. Mais adiante, vamos nos deter no professor televisivo, crucial para nossa reflexão sobre o papel do professor em nossas sociedades.

Para o primeiro professor, o professor do livro, conhecimento deriva de sua inserção numa poderosa cadeia narrativa, sendo ele o portador físico, material, de histórias humanas. Esse professor convida você a se tornar um contador de histórias você mesmo, ou seja, para se tornar parte do grupo humano. O segundo professor, o professor teatral, aparece como a figura totêmica do homem de pé, à vista de todos: a presença do corpo de um ser humano ao mesmo tempo paralisa e mobiliza o pensamento. Tempo e pertencimento cultural não estão tão em questão aqui como a questão da alteridade: o aprendizado é o processo de confrontação com a beleza e a feiúra da voz, do gesto, do corpo de um outro alguém. $\mathrm{O}$ terceiro professor, o professor televisivo, graciosamente empresta seu olhos - e, nesse lento processo de acomodação num corpo de outra pessoa, o aluno aprende a ver por si só, apesar de que as origens desse olhar do outro não são nunca completamente apagadas. Rearranjando cores e objetos e assim dando-lhes significado, esse professor traz para um mundo caótico e sujo um tipo de beleza e comunicabilidade, ao mesmo tempo em que nos ajuda a tolerar a falta de sentido que é parte do 
percurso da linguagem. O último professor em minha tipologia pessoal, o professor telegráfico, impõe sua palavra a cada equilíbrio que, ainda que frágil, tenha sido obtido. As coisas se estilhaçam ou viram do avesso, prazeres são delimitados ou questionados. Nenhum modo de pensar ou agir ou ser é proposto ou ensinado, mas cada um desses modos é desmanchado por palavras, ao mesmo tempo em que são ancorados em sentenças que se instalam como uma praga. A referência mediática desse professor crítico é o telégrafo, pois é esse meio - ou seus congêneres, as manchetes de jornal, os e.mails de "breaking news" que pulam em nossas telas - que têm papel perturbador. Uma pequena sentença vinda de longe pode nos trazer as tristezas de povos distantes e acima de tudo lembrar-nos de nosso próprio desabrigo. De longe, nem ajudar podemos: o telégrafo nos lembra também de nossa impotência.

\section{O homem que sabia}

Conheci uma vez um homem que sabia. Ele não era bonito, mas sabia e me convidou para um almoço. Esperou por mim pacientemente, enquanto eu o fazia esperar distraída. Nós olhamos antigüidades nas lojas e ele me disse que gostava de móveis brasileiros de madeira. Imaginei sua casa cheia de livros e de móveis coloniais, cada um falando do outro. Era um dia de sol, e nós andamos, sentamos, comemos. Ele era um advogado judeu argentino, um ativista em direitos humanos. Ele sabia. Ele me contou sobre a geração sionista, que tinha vindo logo antes dele, mas do jeito que ele falou de seus sonhos, guerras, sonhos guerreados, parecia que ele era um avô falando de crianças machucadas no parquinho. Havia algo seco nele, comemos feijão com farinha de mandioca. Ele me contou dos jogos políticos entre Arafat e os países árabes antes do New York Times explicar as tais filantropias sauditas. Ele era um homem, e sabia coisas.

Ele esteve uma vez no elevador com Dom Paulo Evaristo Arns, quando tentavam ações conjuntas em defesa dos direitos humanos. O bispo disse, com um suspiro de alívio ou lamento: "Vê o que eles nos forçam a fazer?" Ele me contou outras histórias também, histórias que agora não sei se li, se ouvi, ou vivi. Ele mencionou livros e livros, mais rápido do que eu podia assimilar, e eu imaginei a biblioteca de seus avós em Hamburgo e a sóbria sinagoga alemã que eles freqüentavam. Sorri um sorriso feminino porque os livros ficavam pesados.

Me seduza de outro modo!

Mas o único jeito que ele sabia era sabendo.

Ele desconfiava dos judeus religiosos. Onde vão nos levar? Ele gostava 
de uísque, da sagrada companhia feminina, e de uma bilbioteca onde também havia Deus.

Treze anos antes uma história minha tinha sido publicada numa revista que ele publicava. Então ele era mesmo papel e tinta, ele era o lugar onde as histórias se imprimiam. Eu era o quê? Eu era o riso das sílabas? Ele era um livro e eu perguntei a ele uma pergunta. Fazia muito tempo que eu não perguntava algo a um homem, e dessa vez perguntei com o puro desejo de saber, com fé, sem querer agradar ou questionar. Perguntei a ele em lágrimas, porque é tão difícil simplesmente perguntar uma coisa a alguém.

- Por que é que quando eu era criança eu lia sobre o Holocausto em segredo?

- Porque a violência é obscena.

\section{O homem que era}

Evitei-o por mais de uma semana. Se eu ouvia ele chegando para uma visita, discretamente saía para ver alguma amiga. Eu estava tão orgulhosa de meu pai que era quase uma vergonha.

Tudo aconteceu por acaso. Eu estava deixando a Bienal do Ibirapuera depois da conferência "Arquitetura da Violência" e notei que o velho no pequeno carro branco ao meu lado era meu pai. Gritei, buzinei, mas nada. Deixei o estacionamento e retornei, ansiosa para encontrá-lo na escuridão do parque de Niemeyer. Ali estava ele, saindo do carro, pai, pai! Ele me olhou como se não tivesse me reconhecido, quem é essa mulher me chamando de pai?

Ele me convidou para ir para a cerimônia de entrega de prêmios na Bienal, animadíssimo por termos nos encontrado assim, sem planos, num lugar pouco usual.

Eles tinham sido seus alunos, os premiados. Construíram áreas inteiras de São Paulo, estavam em comitês. Eles tinham estudado desenho arquitetônico com ele no Anglo, para fazer a prova da FAU, ou na escola de arquitetura do Mackenzie. "Pait, o professor de todos nós!", alguém gritou no corredor depois da cerimônia. Eu me perguntava como ele se sentia, tendo construído tão pouco, ali ao lado da elite arquitetônica de São Paulo. Ele vai sentir um gosto amargo depois que todos os prêmios forem distribuídos?

- Tudo bem, pai? - eu perguntei.

- Ah, claro! - Ele parecia feliz. Um tinha estudado com ele no Mackenzie, outro era uma excelente pessoa, ele mapeava para mim.

- É de direita ou esquerda? - eu quis saber, mas sua cara me dizia que lá pelos setenta isso não faz tanta diferença. 
Meu pai deu aulas nos anos 60 para complementar sua renda como arquiteto, mas depois teve que encarar um emprego numa companhia de alumínio para sustentar a família e deixou as aulas de lado. Ele desenhava fachadas cortina, o logotipo da companhia era dele, mas isso eram apenas bônus para as construtoras. Ele gostava do chão da fábrica, máquinas, operários, cheiros e barulhos, então acho que ele tinha mágoas por ter deixado a arquitetura e ao mesmo tempo gostava do seu trabalho. "A vida devia ser mais", ele me disse um dia. Bem mais tarde ele começou a fazer esculturas em metal, forma e cor puras, sem clientes, sem patrão. Foi só aí que ele voltou a dar aulas, novamente para complementar a renda. Nunca o vi como professor.

A cerimônia tinha acabado e fomos ao coquetel. Meu pai cumprimentou os premiados com seu estilo efusivo, italianado, e me apresentou a eles, que foram gentis, legais, mas isso era tudo o que eram. Conheci o curador da exposição da Bienal, mas não me lembro de um rosto, uma palavra. Notei apenas que as pessoas cumprimentavam os premiados de modo meio solene, como se não houvesse muito o que cumprimentar, eram eles os arquitetos da violência? São Paulo era uma cidade de que nos orgulhávamos? Tinham valido a pena aquelas vidas na prancheta?

Foi aí que os alunos chegaram. Os dos anos 90, mais jovens do que eu. Pait, Pait, eles gritavam, como se afinal tivessem encontrado algo valioso. Páitchi, Páitchi, soava. Pait, estou tão feliz de te ver. Pait, um deles falou, como se contasse um segredo, sabe aquela cadeira que você nos mandou desenhar? Arrumei um emprego por causa daquela cadeira, levei o emprego. Ei, pessoal, olha quem está aqui, o Pait, as meninas disseram, cheias de maquiagem e saltos altos. Ah, Pait, você é tão fofinho, ai meu Deus. Meu pai apertou suas bochechas. Pait, continua, por favor, continua sendo quem você é, um menino falou, meio hipnotizado, dando esse estranho conselho a alguém que não tinha assim tanto tempo para mudar.

Não conseguíamos ir embora. Eu estava cansada e os alunos não tinham fim, continuavam chegando. Não havia mais ninguém no coquetel, só eu, meu pai e a fila de estudantes que não nos deixava ir embora. Pait, um deles disse no final da conversa, parabéns. Parabéns, Pait. Ele olhava meu pai fixamente, num longo aperto de mãos, cumprimentando-o por um prêmio que ele não tinha levado.

E eu fiquei com esse orgulho que não podia nem tolerar. Dirigi até a casa de uma amiga, tentei explicar o que havia acontecido, e como meu pai era realmente o professor, sabe? Ele é o professor, e chamam ele de Pait, e ele mesmo não quer ser chamado de professor, ele quer ser chamado desse jeito: Pait. Ele é o Pait, ele me contou. E que ele não tinha mesmo construído prédi- 
os altos e fortes em São Paulo, mas que ele era uma espécie de força ele mesmo, fumando e carregando livros pra cima e pra baixo para mostrar aos alunos, e fazendo piadas e carregando os cigarros com o mesmo amor distraído com que ele carregava seu sotaque paulistano, e forte em suas pernas e braços e especialmente em suas mãos precisas que desenhavam, dobravam e perfuravam e atarrachavam. Turma, trabalho, vamos lá! Ele era sólido e firme como um prédio bem projetado, sem saber, como um prédio, que ele mesmo era desenhado, construído, visto e vivido.

\section{A mulher que olhava}

Ela apontou para um enorme cogumelo laranja que crescia num pau podre no bosque.

E nós olhávamos para ele insistentemente, focando, os três pares de óculos se ajustando à cor e à luz e à textura do cogumelo laranja.

Eu me perguntava o que mais ela via, o que mais ela via com sua miopia que eu com a minha não podia ver. Ela punha a meia direita no meu pé direito, e eu nunca descobri como é que ela diferenciava uma da outra.

Ela olhava para todas aquelas caixas e malas e pacotes que nós precisávamos para ir à praia, e nesses longos minutos de silêncio, seus olhos indo da bagagem no chão para o porta-malas do Fusca e de volta para a bagagem, seu rosto calculava e arrumava os pacotes por forma e tamanho nos buracos do Fusca, nós éramos todos expectativa. Aí ela daria ordens e em 10 minutos a bagagem toda tinha desaparecido, miraculosamente comprimida no Fusca e nós na estrada.

Bem depois ela se apoiava na janela depois do jantar, fumando e bebericando, olhando as luzes de São Paulo e eu ainda me perguntava o que ela via na noite.

Às vezes olhávamos uma nos olhos da outra, e aí nossas miopias se cancelavam de algum modo, e víamos mais do que podíamos ver.

$\mathrm{Na}$ verdade ainda ouço sua risada engolindo o mundo, e cada prato que eu como, cada homem que eu beijo e cada livro que eu leio eu beijo pelos olhos dela.

\section{A mulher que falava}

Tínhamos 60 anos de diferença, mas quando ela apoiava seu braço na mesa branca eu sabia que esses braços logo seriam meus.

De vez em quando um de nós chegava em casa todo contente e descrevia a visita à sua casa em detalhes: as almôndegas e o molho de tomate com 
ervilhas, a toalha verde quadriculada, o chocolate europeu escondido em algum canto da casa, a conversa inteligente e compreensiva, o barulho abafado de carros na Avenida Angélica, o prazer de um novo amigo. Nós o escutávamos completamente surpresos e lembrávamos de nossas próprias vistas prazerosas.

Mas raramente visitávamos nossa avó: ao invés disso ela vinha em casa todo fim-de-semana, à nossa cobertura na Vila Madalena. Ela abria a porta com suas próprias chaves quando ainda preparávamos o café, tendo acordado cedo e pego o ônibus. "Ah, Mein Gott, as cortinas! Uma casa sem cortinas é uma casa nua!”, ela dizia invariavelmente. Esse era o começo do domingo. A casa era minimalista, meu pai sendo um arquiteto modernista e minha mãe uma pessoa prática, entusiasmada com suas idéias: ótimo, uma coisa a menos para pensar.

Não era que meu cabelo estava despenteado, a risca era um caminho de ratos. Nossa casa não era meio bagunçada, era um cortiço. Não era que o tapete estava dobrado, era que ela iria tropeçar, cair, quebrar a perna - e quem tomaria conta dela? Todos os problemas levantados, conseqüências previstas.

Se em nossa legítima defesa de nosso divino dia de descanso nós resistíssemos aos seus comentários, ela viria com essa: "Vocês têm pedras nas mãos. Eu não sei o que têm contra mim!" Ela gostava da comida que a Terezinha fazia para nós - "É um inimigo que se tem na própria casa". Mas censurava nosso comportamento à mesa com palavras que iam ao cerne do ato de comer: "Você tem um avô que era gordo!", ela lembrava o meu irmão, com seu Português pausado e correto, cada palavra pronunciada com reflexão e intenção.

- Pára vai, por favor, pára!

Sua vitória final:

- A verdade dói.

Havia algo a respeito de livros e vida intelectual que a irritava bastante, algo que nós entendemos só muito depois, algo óbvio. Mas naquele tempo se ela me visse curtindo o fim-de-semana no sol, um livro ou revista à minha frente, ela me acusava: "Ninguém ajuda a Rosa: você está matando a sua mãe." E se o livro fosse escrito pela Clarice Lispector, uma expressão de desprezo e nojo me censuraria como se eu estivesse lendo pornografia. Eram todos pornográficos, aqueles meus livros?

Suas palavras desfaziam tudo, congelavam tudo em frases que nós não conseguíamos romper. A Lilian dá medo. Com o Alex não se pode falar. Ela estava certa, uma casa fica nua sem cortinas, e ali estava, uma casa, nós, nus, incapazes de desajeitadamente nos cobrir em palavras. 


\section{O professor televisivo}

Essas quatro narrativas contam como quatro professores interpretam ambientes mediáticos distintos e os usaram a seu favor. Eles não sucumbem a esses ambientes, não se tornam meros facilitadores de um processo mecânico de aprendizado. Mantêm-se no centro de uma relação humana, no papel de outro que se encontra defronte a uma audiência e que deve, para o bem ou para o mal, ser alguém, olhar, contar, escutar. Eles se oferecem aos estudantes, generosamente, em sua nudez, diria Lévinas. Mas fazem isso sem esquecer os ambientes comunicativos nos quais se inserem, garantindo que seus ensinamentos façam sentido para essa platéia e, mais que isso, que dêem sentido à comunicação no entorno.

O professor do livro, por exemplo, se apresenta como a própria incorporação das narrativas, como uma verdadeira coleção de livros. O conhecimento é depositado nele mas também na relação de ensino, quando o aluno tem a estranha sensação de que mesmo o seu conhecimento está impresso nesse professor. É o deslumbramento com esse conhecimento aparentemente infinito que faz os alunos continuarem a perguntar, a buscar, a pesquisar: esse conhecimento é a prova de que o saber vale a pena. O crucial nesse modo de aprender é que ele nos liga ao passado e também ao futuro, baseando-se no caráter perene da escrita. Esse professor parece mais velho ainda que as narrativas que nos conta, quase que pairando sobre o tempo, nos ligando à humanidade como um todo. Ele media o tempo. Não digo que ele usa o livro para ensinar, ou que sabe o que os livros contêm, mas sim que ele é o livro. Que se coloca no lugar do livro, dando-lhe significado: os livros são o que são por causa dele. E sem ele, tornam-se folhas amarradas cheias de letras espalhadas. Mas quem é que tem hoje tempo para se tornar esse professor que lê e coleciona textos em sua infindável memória? A raridade desse professor clássico pode fazer muitas pessoas pensarem que podemos abrir mão dele, mas a verdade é que não podemos abrir mão de nenhum professor.

O professor teatral é o mais divertido dos professores. Ele interpreta um cirurgião de tal modo que você pode sair da aula pensando: "ei, também posso operar!" Esse professor não nos conta nada: ele incorpora conceitos com total controle sobre sua própria voz, seus gestos, passos e movimentos. Encanta a audiência menos com seu conhecimento do que com ele próprio. Seu meio é o próprio corpo, que nos é apresentado como num espetáculo. Verdade, aqui, é a palavra-chave. A máscara desse professor é a máscara dele mesmo, e a raiva e o entusiasmo que ele finge ter são mesmo dele, como no 
famoso poema de Pessoa. Além do "homem que era", adorado por seu entusiasmo pelo mundo das cidades e dos edifícios, também é exemplo do professor teatral a professora marxista que trouxe para a sala de aula a luta de classes, com sua mútua adoração e desprezo. Marx pode estar errado, e a arquitetura moderna tem seus críticos. Mas no espaço teatral da sala de aula esses conceitos eram bem reais, verdadeiros e vivos. Se o professor do livro trouxe o livro à vida, esse professor traz a própria vida à vida. Ele dá consistência ao encontro humano, torna real o mundo e o pensamento. Fascinando-nos com sua vida vivida, ele nos lembra que tudo é possível, até mesmo estar aqui, na sua frente. É desse professor que lembramos, depois, quando caminhamos por aí, nesse mundo. Num dia-a-dia de bate-papos impessoais, sexo seguro e mais uma gama de percepções orquestradas, o espetáculo de estar junto tira os alunos da imaginação burocrática dos exames, trabalhos e relatórios, de seu perigosíssimo tédio. Ele é aventura.

O professor telegráfico apresenta uma afirmação que deve se sustentar independentemente da resposta recebida. Essa é a essência do telégrafo, que traz notícias de longe sem nos dar chance de respondê-las. O telégrafo cria perturbações na arena local sem de fato conectá-la a uma arena maior de interação. No estudo de Carey (1988) sobre a introdução do telégrafo nos Estados Unidos, por exemplo, preços agrícolas em regiões inicialmente isoladas subiam ou desciam no instante em que esses mercados se ligavam a outros maiores pelo telégrafo, causando perdas ou ganhos para compradores e vendedores locais. O professor telegráfico causa uma ruptura em nossas crenças parecida com isso. Ele é ideológico, no sentido de que tenta trazer a narrativa fluida, mutante, para um ponto de impasse, para suas verdades eternamente repetidas. Como um telégrafo, ele consegue voltar ao momento em que a mensagem foi emitida, a mensagem telegráfica, não-dialógica. A beleza do telégrafo é a perturbação que ele cria, conseqüência da fragilidade em que nos coloca. Ele pode ser ético, pois o que o compele a falar pode ser uma necessidade ética de endireitar as coisas, dizer uma verdade que ele não consegue guardar consigo mesmo, mas ele não é nada dialógico. Ele vem de fora e sentencia: a história da humanidade é a história da luta de classes. Uma casa sem cortinas é uma casa nua. O povo alemão precisa de espaço vital. O preço do milho é 2,36 dólares por bushel. Irrefutáveis sentenças, certas ou erradas. Sua força dramática nos paraliza, humilha, pede uma ação que sabemos, de antemão, será inútil. Ele nos julga: de que lado da luta de classes estamos? Como é que deixamos a casa pelada? Por que não vendemos o milho antes? Como o professor teatral, o espetáculo da voz e do gesto é mais importante que sua sofisticação intelectual, mas esse professor não tem os recursos ima- 
ginativos do ator da vida. Ele é, por outro lado, o melhor crítico de todos, sempre puxando o tapete de nossos pés, e deve ter seu lugar em qualquer sociedade democrática. Goldfarb o chama de "intelectual subversivo" (PAIT, 2000; GOLDFARB, 1998).

E agora, finalmente, analizemos o professor televisivo. Estou usando o termo televisivo em sentido abrangente, definindo uma sociedade televisiva como aquelas onde a televisão nacional é central, mas é complementada pela internet, computadores pessoais, redes internacionais de televisão e telefones celulares. Em outras palavras, é uma combinação entre visualidade e conectividade que define o campo comunicativo de nossas sociedades. Com uma série de narrativas sendo constantemente colocadas à nossa disposição, não estamos exatamente sedentos por narrativas, verdades telegráficas, ou mesmo por espetáculos. Precisamos de pessoas que consigam habitar esse mundo visual, dando-lhe sentido, exatamente como a mulher que olhava conseguia encher o porta-malas. Ao seu próprio mundo falta o sentido que ela busca, metodicamente. Ela constrói uma paisagem onde havia antes apenas mensagens e imagens fragmentadas. Dela esperamos uma visão periscópica, que foca o que é relevante num mar vazio e sem sentido. Como os outros professores, ela não abre mão da tarefa de ser professor, mas reinterpreta o papel docente numa sociedade televisiva. Pode ser que ela destaque uma imagem, uma idéia, ou mesmo um vazio. Numa entrevista para uma rádio pública americana, o músico Tom Waits (2002) negou que tivesse saído da escola por ter maus professores: “Ah, eu tive bons professores. Mas eu queria ver o mundo. E meus professores também pareciam não ver a hora de sair de lá e ver o mundo também." Os professores do músico olhavam o vazio.

O papel da professora televisiva vai então além de organizar o caos visual e verbal em que vivemos, destacando o relevante. "Eu me perguntava o que mais ela via, o que mais ela via com sua miopia que eu com a minha não podia ver." O cerne de sua tarefa é esse olhar que ela inspira, um olhar profundamente curioso, interessado, sempre em busca do desconhecido. Como posso me libertar de minha própria miopia, mesmo que eu vá encontrar a miopia de outra pessoa logo à frente? Esse "o que mais" é o que nos liga ao outro, essa pergunta sobre as visões de mundo e os desejos do outro, ou mesmo sobre o passado e o conhecimento desse outro. É o que chamei de silêncio em minha tese, um desejo tranqüilo de alcançar o outro, mesmo se soubermos de antemão que esse alcance é impossível. Está relacionado com a idéia de fascínio de Benjamin (ABBAS, 1989), ou de quiasma em Merleau-Ponty (1968) ou mesmo de êxtase para Nancy e Bataille (NANCY, 1991) Como na comunicação televisiva, as respostas chegam quando as perguntas já se foram. O verda- 
deiro conhecimento se dá quando estamos tateando em direção a um outro, ao desconhecido.

A mulher que olhava não seduz com sua presença, como o professor teatral. Não paralisa nosso raciocínio com nenhuma verdade anunciada, e se ela nos traz para uma cadeia humana não é por meio de uma narrativa histórica. Ela faz isso com o repentino movimento de olhar para você. E aí você tem que existir na frente dela, falar, agir, ser parte do jogo. Ela transfere ao aluno sua própria habilidade de olhar, de dar sentido, de alcançar outros seres humanos. Na sala de aula, ela escuta, mais do que conta. É curiosa a respeito do que dizem e pensam os alunos mais do que enamorada por suas próprias idéias e falas. Ela os ajuda a compreender seus próprios processos de pensamento, que lhe são fascinantes. Como não parece ser tão distante assim, acaba sendo às vezes confundida com o próprio aluno, e deixa seus ensinamentos passarem despercebidos.

Há uma grande generosidade envolvida aí, a generosidade de escutar, de procurar compreender um raciocínio que se forma, e isso às vezes deixa essa própria professora um pouco confusa: "Então sou eu que estou aprendendo?" Mas ela permanece como professora, sem desfazer a necessária assimetria da relação professor-aluno. Pois essa figura que escuta é absolutamente necessária num mundo onde a escuta, mais do que a informação, é um bem raro. Todos os professores anteriores se expõem na sala de aula: aí é que está seu poder ensinador. O que a professora televisiva expõe, silenciosamente, é seu olhar que abarca o espaço presente, que dá sentido e continuidade a um espaço fragmentado, e que busca o outro nesse espaço humanizado. Se o professor do livro é o livro mesmo, ela é a tela de televisão humanizada, que nos abre para o mundo, que nos ensina a viver com a distância.

Não consigo terminar esse artigo sem algumas palavras sobre Os desastres de Sofia, de Clarice Lispector (1992). Como notou Pontieri (1999), a prosa de Clarice tem em comum com a filosofia de Merleau-Ponty (1968) a ênfase da escritora no olhar e na visão, e nesse conto em particular isso fica muito claro. A espevitada Sofia provoca seu mestre até que esse a enxergue. O olhar perturbador do professor, olhar de barata, muda a história. Sofia aprende a ser gente, descobre que seu mundo "bobo" de fantasia é também compartilhado pelos adultos. Viu no professor o mundo, e viu nesse professor em particular não por sua cultura ou presença, uma vez que ele era feio, desajeitado, ingênuo. Ela vê o mundo nele porque ele a olhou. Só isso. Leu sua história bonita.

Num mundo onde o olhar é fragmentado, onde não sabemos quem nos olha ou por quem somos vistos, ver o mundo é crucial: dar sentido à visão. E 
isso só acontece se formos olhados atentamente, com nada menos que o olhar de barata do esquisito professor, ou de nossa idiossincrática professora televisiva.

\section{Conclusão}

Nesse artigo mostramos que viver com as fraturas temporais e espaciais dos meios de comunicação é bem desafiador, e que isso demanda um diálogo imaginário com participantes desconhecidos do ambiente mediático. As maneiras de habitar esses ambientes não surgem diretamente deles, mas sim de esforços criativos de seus participantes. $\mathrm{O}$ papel dos professores nesse processo não pode ser superestimado. Suas próprias batalhas nesses complexos espaços comunicativos se constituem no nosso espetáculo, e é por meio dele que aprendemos a participar de modo inteligente nesses espaços. $\mathrm{O}$ aprendizado pode mudar conforme o ambiente comunicativo. Mas é a visão de um ser humano habitando esse espaço que não muda.

Quis trazer a discussão sobre mídia e ensino para um plano filosófico e também narrativo. Mas o leitor pode estar querendo recursos práticos para enfrentar a sala de aula em concorrência mesmo com os meios de comunicação, o que é mais que legítimo. Esse é o tema do artigo que estou escrevendo no momento, que relata e propõe exercícios, discussões em sala de aula e métodos de avaliação que procuram fazer da sala de aula de cursos em ciências sociais em nível superior algo rico e dinâmico. Mas esses recursos afloraram de minha reflexão sobre o ensino na era da comunicação, dos exemplos docentes que me marcaram mais profundamente e do encontro vivo e cheio de suspresas que tive com os alunos, muitas vezes também surpresos com meu interesse por suas idéias, estudos e projetos. Espero que o presente artigo seja uma contribuição a essa busca docente, mas sei que cada professor, quando entra numa sala de aula, conta apenas com seus próprios recursos, sua história e seus sonhos. 


\section{REFERÊNCIAS}

ABBAS, A. On fascination: Walter Benjamin's images. New German Critique, Ithaca, NY, v.16, n. 48, p. 43-62, Fall 1989.

ARENDT, H. A condição humana. Rio de Janeiro: Forense Universitária, 2003.

BERTOLINI, M. et al. Squiggles and spaces: revisiting the work of D.W. Winnicott. London: Whurr, 2001.

CAREY, J. Communication as culture. Boston: Unwin Hyman, 1988.

CAVELL, S. The fact of television. Daedalus, v. 111, n. 4, p.74-96, Cambridge, MA, Fall, 1982.

DEBRAY, R. Media manifestos: on the technological transmission of cultural forms. London; New York: Verso, 1996.

FISKE, J. Television culture. London; New York: Routledge, 1997.

GOLDFARB, J. C. Civility and subversion: the intellectual in democratic society. New York: Cambridge University Press, 1998.

GUMBRECHT, H. U.; PFEIFFER, K. L. (Orgs.). Materialities of communication. Stanford, California: Stanford University Press, 1994.

LÉVINAS, E. Totality and infinity: an essay on exteriority. Boston: Kluwer, 1981.

LISPECTOR, C. A legião estrangeira. São Paulo: Siciliano, 1992.

MCLUHAN, M. Understanding media: the extensions of man. Cambridge, Mass: MIT Press, 1994.

MERLEAU-PONTY, M. The visible and the invisible; followed by working notes. Evanston, Ill.: Northwestern University Press, 1968.

MEYROWITZ, J. No sense of place: the impact of electronic media on social behavior. New York: Oxford University Press, 1985.

NANCY, J. L. The inoperative community. Minneapolis: University of Minnesota Press, 1991.

O'SHAUGHNESSY, E. W. R. Bion's theory of thinking and new techniques in child analysis. In: SPILLIUS, E. B. (Org.). Melanie Klein today: developments in theory and practice, vol. 2: mainly practice. London: Tavistock, Routledge, 1988. p. 177190.

PAIT, H. Conversar, ainda o grande problema dos homens: entrevista com Jeffrey Goldfarb. Jornal da Tarde, São Paulo, 09 jan. 2000, Caderno Domingo, p. 6D. 
. Scenes and silences of television: Brazilian soap operas and the construction of public spaces. Ann Arbor: UMI Dissertation Services, 2003.

. The town of Asa Branca: constructing public spaces in Brazil. The Communication Review, Philadelphia, PA, v. 8, n. 1, p. 53-77, 2005a.

. O silêncio da televisão: desafios e esperanças da comunicação mediada. In: SEMINÁRIO DE PESQUISA MEMÓRIA E CONTEMPORANEIDADE, 4., jun. 2005, Campinas, Anais... 2005b.

PALMEN, C. The laws. New York: Braziller, 1993.

PONTIERI, R. Clarice Lispector: uma poética do olhar. São Paulo: Ateliê Editorial, 1999.

SIMMEL, G. On individuality and social forms. Chicago; London: The University of Chicago Press, 1971.

WAITS, T. Interview with Tom Waits [Radio program]. Boston: Fresh Air, NPR, 2002.

WEBER, S. Mass mediauras: form, technics, media. Stanford, California: Stanford University Press, 1996.

Texto recebido em 11 abr. 2005 Texto aprovado em 17 jun. 2005 